Article

\title{
New Cembranolides from the Dongsha Atoll Soft Coral Lobophytum durum
}

\author{
Shi-Yie Cheng ${ }^{1}$, Pei-Wen Chen ${ }^{1}$, Hwa-Pyng Chen ${ }^{1}$, Shang-Kwei Wang ${ }^{2, *}$ and Chang-Yih Duh ${ }^{1,3, *}$ \\ 1 Department of Marine Biotechnology and Resources, National Sun Yat-sen University, \\ Kaohsiung 804, Taiwan; E-Mails: shiyie63@yahoo.com.tw (S.-Y.C.); \\ m975020018@student.nsysu.edu.tw (P.-W.C.); m975020801@student.nsysu.edu.tw (H.-P.C.) \\ 2 Department of Microbiology, Kaohsiung Medical University, Kaohsiung 807, Taiwan \\ 3 Center for Asia-Pacific Ocean Research and Translational Biopharmaceuticals, \\ National Sun Yat-sen University, Kaohsiung 804, Taiwan \\ * Authors to whom correspondence should be addressed; \\ E-Mails: yihduh@mail.nsysu.edu.tw (C.-Y.D.); skwang@cc.kmu.edu.tw (S.-K.W.); \\ Tel.: +886-7-525-2000 (ext. 5036) (C.-Y.D.); +886-7-312-1101 (ext. 2150) (S.-K.W.); \\ Fax: $+886-7-525-5020$ (C.-Y.D.).
}

Received: 4 July 2011; in revised form: 13 July 2011 / Accepted: 22 July 2011 /

Published: 27 July 2011

\begin{abstract}
Chemical investigations of the Dongsha Atoll soft coral Lobophytum durum resulted in the isolation of five new cembranolides, durumolides M-Q (1-5). The structures of compounds 1-5 were characterized by the interpretation of extensive spectroscopic analysis. Compound 4 exhibited cytotoxicity against P-388 (mouse lymphocytic leukemia) cell line with an $\mathrm{ED}_{50}$ of $3.8 \mu \mathrm{g} / \mathrm{mL}$. Moreover, compound 5 showed significant antiviral activity against human cytomegalovirus with an $\mathrm{IC}_{50}$ of $5.2 \mu \mathrm{g} / \mathrm{mL}$.
\end{abstract}

Keywords: soft coral; Lobophytum durum; cytotoxicity; antiviral activity

\section{Introduction}

Various natural products, distributed mainly in marine soft corals of the genus Lobophytum (Alcyoniidae) [1-21], have attracted much attention from chemists specializing in natural products due to their structural complexity and remarkable pharmacological activities such as cytotoxicity [2-9], antibacterial activities [10], anti-inflammatory properties [10-12], and HIV-inhibitory activity [13]. Our previous investigations of the soft coral L. durum (Figure 1) from the Dongsha Atoll have resulted 
in the purification of 15 cembranolides, durumolides $\mathrm{A}-\mathrm{L}$ and durumhemiketalolides $\mathrm{A}-\mathrm{C}$, several of which showed antibacterial and anti-inflammatory activities [10-12]. Our continuing chemical examinations of the bioactive substances of this organism led to the isolation of five new cembranolides, designated as durumolides M-Q (1-5) (Figure 2). The structures of compounds 1-5 were determined on the basis of detailed 1D and 2D NMR experiments, mainly employing COSY, DEPT, HMBC, HSQC, and NOESY spectra. Moreover, durumolides M-Q were evaluated in vitro for the cytotoxicity against A-459 (human lung adenocarcinoma), HT-29 (human colon adenocarcinoma), and P-388 (mouse lymphocytic leukemia) cancer cell lines, and antiviral activity against human cytomegalovirus.

Figure 1. Soft coral Lobophytum durum.

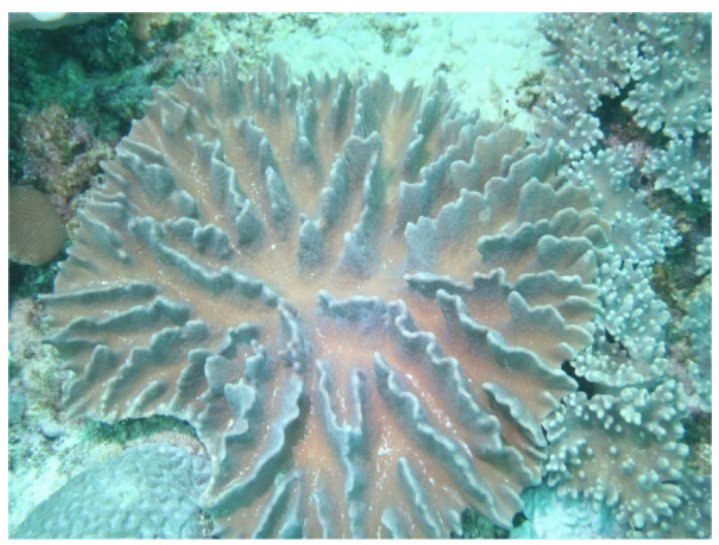

Figure 2. Structures of compounds 1-5.<smiles>CO[I+][C@H]1C(=O)O[C@H]2C(O)/C(C)=C\CC/C(C)=C\CC[C@@]3(CO)O[C@@H]3C[C@H]12</smiles><smiles>[R]C[C@]1(CC/C=C(/C)CC/C=C(\C)C(O)[C@H]2OC(=O)[C@@H](COC)[C@H]2C[C@H]2OC2(C)C)CO1</smiles>

$2 \mathrm{R}=\mathrm{H}$

$3 \mathrm{R}=\mathrm{Ac}$

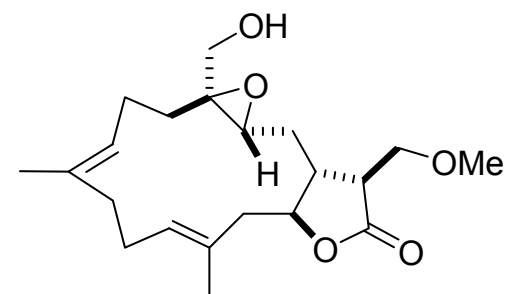

4

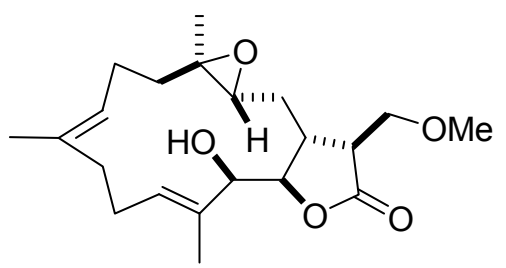

5

\section{Results and Discussion}

Specimens of L. durum were frozen immediately after collection. Conventional extraction procedures were used, and the acetone extract was exhaustively partitioned between EtOAc and $\mathrm{H}_{2} \mathrm{O}$ to afford the EtOAc-soluble fraction, which was evaporated under vacuum to yield a dark brown gum 
$(30 \mathrm{~g})$. The concentrated residue was subjected to column chromatography and high-performance liquid chromatography (HPLC), leading to the purification of $\mathbf{1}-\mathbf{5}$.

Durumolide M (1), appeared as a colorless oil, exhibited a high resolution electrospray ionization mass spectrometry (HR-ESI-MS) pseudomolecular ion peak at $m / z 403.2099[\mathrm{M}+\mathrm{Na}]^{+}$, corresponding to a molecular formula of $\mathrm{C}_{21} \mathrm{H}_{32} \mathrm{O}_{6}$ and six degrees of unsaturation. Comparison of the NMR data (Tables 1 and 2) of 1 with those of sinularolide B [22] revealed that $\mathbf{1}$ was determined to be a 17-methoxylated analogue of sinularolide $\mathrm{B}$, coinciding with methoxyl protons at $\delta_{\mathrm{H}} 3.30(3 \mathrm{H}, \mathrm{s})$ correlated to the oxymethine carbon at $\delta_{\mathrm{C}} 70.0(\mathrm{C}-17)$, and oxymethylene protons at $\delta_{\mathrm{H}} 3.81(1 \mathrm{H}$, dd, $J=9.2,2.8 \mathrm{~Hz}, \mathrm{H}-17 \mathrm{a})$ and $3.73(1 \mathrm{H}, \mathrm{dd}, J=9.2,2.8 \mathrm{~Hz}, \mathrm{H}-17 \mathrm{~b})$ correlated to the methine carbons at $\delta_{\mathrm{C}} 40.8(\mathrm{C}-1)$, and $44.5(\mathrm{C}-15)$, as well as the lactone carbonyl carbon at $\delta_{\mathrm{C}} 176.9(\mathrm{C}-16)$ in the HMBC spectrum (Figure 3). Thus, the planar structure of durumolide $M$, possessing an $\alpha$-methoxymethyl- $\gamma$-lactone ring fused to a 14 -membered ring at $\mathrm{C}-1$ and $\mathrm{C}-14$, was, with certainty, assigned as $\mathbf{1}$.

Table 1. ${ }^{1} \mathrm{H}$ NMR data for compounds $\mathbf{1}-\mathbf{3}$.

\begin{tabular}{|c|c|c|c|}
\hline & $\mathbf{1}^{a}$ & $2^{b}$ & $3^{b}$ \\
\hline 1 & $2.28 \mathrm{~m}$ & $2.41 \mathrm{~m}$ & $2.40 \mathrm{~m}$ \\
\hline \multirow[t]{2}{*}{2} & $1.75 \mathrm{dt}(14.8,2.4)^{c}$ & 1.97 ddd $(14 . .5,2.0,2.0)$ & 2.00 br d (14.5) \\
\hline & 1.67 ddd $(14.8,7.6,2.4)$ & $1.37 \mathrm{ddd}(14.5,8.0,2.5)$ & $1.21 \mathrm{ddd}(14.5,8.5,1.5)$ \\
\hline 3 & $2.67 \mathrm{dd}(7.6,2.4)$ & $2.73 \mathrm{dd}(8.0,2.5)$ & $2.69 \mathrm{dd}(8.5,1.5)$ \\
\hline \multirow[t]{2}{*}{5} & $2.43 \mathrm{~m}$ & $2.39 \mathrm{~m}$ & $2.38 \mathrm{~m}$ \\
\hline & $1.11 \mathrm{ddd}(14.8,13.2,3.6)$ & $1.11 \mathrm{ddd}(14.5,13.0,3.5)$ & $1.08 \mathrm{ddd}(15.0,13.5,3.5)$ \\
\hline \multirow[t]{2}{*}{6} & $2.31 \mathrm{~m}$ & $2.32 \mathrm{~m}$ & $2.29 \mathrm{~m}$ \\
\hline & $2.10 \mathrm{~m}$ & $2.14 \mathrm{~m}$ & $2.15 \mathrm{~m}$ \\
\hline 7 & $5.04 \mathrm{dd}(7.2,4.4)$ & $5.08 \mathrm{dd}(7.5,4.5)$ & $5.07 \mathrm{dd}(7.0,4.0)$ \\
\hline \multirow[t]{2}{*}{9} & $2.39 \mathrm{~m}$ & $2.35 \mathrm{~m}$ & $2.37 \mathrm{~m}$ \\
\hline & $2.13 \mathrm{~m}$ & $2.16 \mathrm{~m}$ & $2.20 \mathrm{~m}$ \\
\hline \multirow[t]{2}{*}{10} & $2.55 \mathrm{~m}$ & $2.51 \mathrm{~m}$ & $2.53 \mathrm{~m}$ \\
\hline & $2.16 \mathrm{~m}$ & $2.19 \mathrm{~m}$ & $2.17 \mathrm{~m}$ \\
\hline 11 & $5.45 \mathrm{dd}(6.8,4.0)$ & $5.49 \mathrm{dd}(6.8,3.5)$ & $5.50 \mathrm{dd}(6.5,3.0)$ \\
\hline 13 & $3.97 \mathrm{~d}(8.8)$ & $4.11 \mathrm{~d}(8.5)$ & $4.08 \mathrm{~d}(8.5)$ \\
\hline 14 & $4.20 \mathrm{dd}(9.2,8.8)$ & $4.06 \mathrm{t}(8.5)$ & $4.04 \mathrm{dd}(9.0,8.5)$ \\
\hline 15 & $2.86 \mathrm{dt}(9.2,2.8)$ & $2.50 \mathrm{dt}(10.5,2.5)$ & $2.49 \mathrm{dt}(9.5,2.5)$ \\
\hline \multirow[t]{2}{*}{17} & $3.81 \mathrm{dd}(9.2,2.8)$ & $3.81 \mathrm{dd}(10.5,2.5)$ & $3.81 \mathrm{dd}(9.5,2.5)$ \\
\hline & $3.73 \mathrm{dd}(9.2,2.8)$ & $3.79 \mathrm{dd}(10.5,2.5)$ & $3.79 \mathrm{dd}(9.5,2.5)$ \\
\hline \multirow[t]{2}{*}{18} & $3.87 \mathrm{dd}(12.0,6.0)$ & $3.84 \mathrm{~d}(12.0)$ & $4.44 \mathrm{~d}(12.5)$ \\
\hline & $3.57 \mathrm{dd}(12.0,4.8)$ & $3.54 \mathrm{~d}(12.0)$ & $3.77 \mathrm{~m}$ \\
\hline 19 & $1.62 \mathrm{~s}$ & $1.62 \mathrm{~s}$ & $1.64 \mathrm{~s}$ \\
\hline 20 & $1.71 \mathrm{~s}$ & $1.70 \mathrm{~s}$ & $1.70 \mathrm{~s}$ \\
\hline 17-OMe & $3.30 \mathrm{~s}$ & $3.39 \mathrm{~s}$ & $3.38 \mathrm{~s}$ \\
\hline 18-OAc & & & $2.13 \mathrm{~s}$ \\
\hline
\end{tabular}

${ }^{a}$ Spectra were measured in $\mathrm{CDCl}_{3}(400 \mathrm{MHz}) ;{ }^{b}$ Spectra were measured in $\mathrm{CDCl}_{3}(500 \mathrm{MHz})$; ${ }^{c} J$ values (in $\mathrm{Hz}$ ) are in parentheses. 
Table 2. ${ }^{13} \mathrm{C}$ NMR data for compounds $\mathbf{1}-\mathbf{5}$.

\begin{tabular}{cccccc}
\hline & $\mathbf{1}^{a}$ & $\mathbf{2}^{b}$ & $\mathbf{3}^{b}$ & $\mathbf{4}^{a}$ & $\mathbf{5}^{a}$ \\
\hline 1 & 40.8 & 38.6 & 38.7 & 40.8 & 38.7 \\
2 & 25.0 & 31.4 & 31.4 & 31.0 & 32.2 \\
3 & 64.3 & 63.9 & 63.1 & 63.7 & 63.8 \\
4 & 62.1 & 62.2 & 59.9 & 62.5 & 59.5 \\
5 & 33.3 & 33.5 & 32.9 & 33.3 & 38.3 \\
6 & 24.1 & 24.2 & 24.3 & 24.7 & 24.9 \\
7 & 124.5 & 124.5 & 124.3 & 124.4 & 124.6 \\
8 & 135.0 & 135.1 & 135.2 & 135.3 & 134.6 \\
9 & 39.0 & 38.9 & 38.9 & 39.3 & 38.9 \\
10 & 24.7 & 24.7 & 24.8 & 23.8 & 24.8 \\
11 & 132.0 & 131.9 & 132.2 & 130.2 & 132.3 \\
12 & 132.4 & 132.0 & 132.0 & 129.9 & 131.9 \\
13 & 82.0 & 80.9 & 81.2 & 43.7 & 81.4 \\
14 & 84.1 & 82.2 & 81.9 & 80.1 & 82.2 \\
15 & 44.5 & 49.4 & 49.3 & 49.8 & 49.5 \\
16 & 176.9 & 175.4 & 175.3 & 176.2 & 175.6 \\
17 & 70.0 & 68.1 & 67.8 & 68.5 & 67.9 \\
18 & 61.8 & 61.5 & 63.7 & 61.5 & 16.3 \\
19 & 15.3 & 15.2 & 15.3 & 15.0 & 15.2 \\
20 & 12.2 & 12.3 & 12.1 & 17.1 & 12.0 \\
$17-O M e$ & 59.1 & 59.3 & 59.3 & 59.2 & 59.3 \\
$18-O A c$ & & & 20.8 & & \\
& & & 170.9 & & \\
\hline
\end{tabular}

${ }^{a}$ Spectra were measured in $\mathrm{CDCl}_{3}(100 \mathrm{MHz}) ;{ }^{b}$ Spectra were measured in $\mathrm{CDCl}_{3}(125 \mathrm{MHz})$.

Figure 3. Selected ${ }^{1} \mathrm{H}-{ }^{1} \mathrm{H} \operatorname{COSY}(-)$ and $\operatorname{HMBC}(\rightarrow)$ correlations of $\mathbf{1}$.

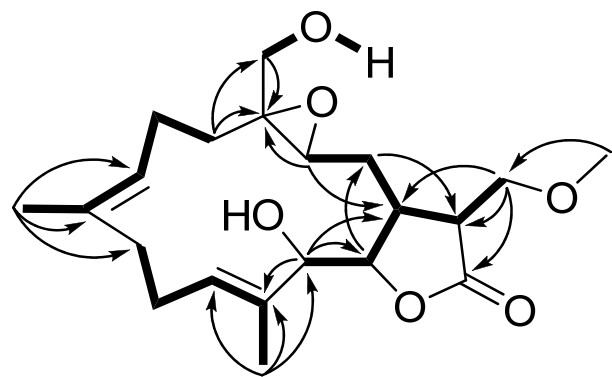

The geometries of the two trisubstituted olefins were proposed as both $E$ based on the $\gamma$-effect of the olefinic methyl signals for C-19 and C-20 (less than $20 \mathrm{ppm}$ ) and the NOESY correlations between $\mathrm{H}-7 / \mathrm{H}-9 \mathrm{~b}$ and $\mathrm{H}-11 / \mathrm{H}-13$ (Figure 4). Compound 1 possessed the same configurations as sinularolide $\mathrm{B}$ at the $\mathrm{C}-1, \mathrm{C}-3, \mathrm{C}-4, \mathrm{C}-13$, and $\mathrm{C}-14$ stereocenters due to the similar NOESY correlations between H-1/H-3, H-1/H-13, H-11/H-13, H-11/H-9b ( $\delta$ 2.13), H-3/H-5b ( $\delta$ 1.11), H-14/H-2a $(\delta 1.75)$, H-7/H-9b, and $\mathrm{H}-14 / \mathrm{H}_{3}-20$. Moreover, the large coupling constant $(J=9.2 \mathrm{~Hz})$ between $\mathrm{H}-1$ and $\mathrm{H}-15$ suggested that the vicinal protons were either in an anticoplanar or eclipse relationship. The latter relationship should be correct because the signal at $\delta_{\mathrm{H}} 2.86(1 \mathrm{H}, \mathrm{dt}, J=9.2,2.8 \mathrm{~Hz}, \mathrm{H}-15)$ showed a strong NOESY 
correlation with $\delta_{\mathrm{H}} 2.28(1 \mathrm{H}, \mathrm{m}, \mathrm{H}-1)$, implying the $R$ configuration at $\mathrm{C}-15$. On the basis of the above-mentioned observations, the structure of durumolide $\mathrm{M}(\mathbf{1})$ was characterized as $\left(1 R^{*}, 3 R^{*}, 4 S^{*}\right.$, $\left.13 R^{*}, 14 R^{*}, 15 R^{*}, 7 E, 11 E\right)$-13,18-dihydroxy-17-methoxy-3,4-epoxycembra-7,11-dien-16,14-olide.

Figure 4. Selected NOESY correlations of 1.



Compounds 1 and 2 had the same molecular formula $\left(\mathrm{C}_{21} \mathrm{H}_{32} \mathrm{O}_{6}\right)$. Analysis of their ${ }^{1} \mathrm{H}-$ and ${ }^{13} \mathrm{C}-\mathrm{NMR}$ data (Tables 1 and 2 ) revealed that they shared the same cembranolide skeleton, differing only in the configuration of $\mathrm{C}-15$ in 2 . The configuration of $\mathrm{C}-15$ was proposed to be $S$, as identified by its NOESY correlations between $\mathrm{H}-15 / \mathrm{H}-2 \mathrm{~b}, \mathrm{H}-14 / \mathrm{H}-2 \mathrm{~b}$, and $\mathrm{H}_{2}-17 / \mathrm{H}-1$ (Figure 5). Therefore, compound $\mathbf{2}$ was determined to be 15-epimer of $\mathbf{1}$. According to the above findings, the structure of durumolide $\mathrm{N}$ (2) was unambiguously established and elucidated as $\left(1 R^{*}, 3 R^{*}, 4 S^{*}, 13 R^{*}, 14 R^{*}\right.$, $\left.15 S^{*}, 7 E, 11 E\right)$-13,18-dihydroxy-17-methoxy-3,4-epoxycembra-7,11-dien-16,14-olide.

Figure 5. Selected NOESY correlations of 2.

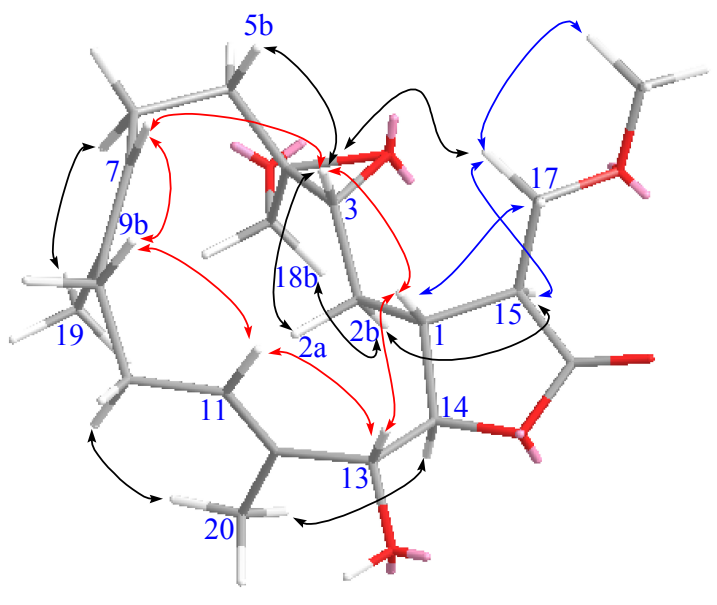

Durumolide O (3) was analyzed for a molecular formula of $\mathrm{C}_{23} \mathrm{H}_{34} \mathrm{O}_{7}$ by its HR-ESI-MS coupled with the DEPT and ${ }^{13} \mathrm{C}$ NMR spectroscopic data (Table 2). Analysis of the ${ }^{1} \mathrm{H}-{ }^{1} \mathrm{H}$ COSY and HMBC correlations were diagnostic in determining that the planar framework of durumolide $\mathrm{O}$, having a 14-membered ring fused to an $\alpha$-methoxymethyl- $\gamma$-lactone ring at $\mathrm{C}-1$ and $\mathrm{C}-14$, was proposed as 3. The structure of $\mathbf{3}$ was identical to that of $\mathbf{2}$ except that the hydroxy group attached to C-18 was 
replaced by an acetoxy group. This assumption was confirmed through the key HMBC correlations from $\mathrm{H}_{2}-18$ to C-3, C-4, C-5, and the carbonyl carbon of 18-OAc. All the NMR data (Tables 1 and 2) of 3, assigned by COSY, HMBC, HSQC, and NOESY correlations, were satisfactorily consistent with the structure shown as $\left(1 R^{*}, 3 R^{*}, 4 S^{*}, 13 R^{*}, 14 R^{*}, 15 S^{*}, 7 E, 11 E\right)$-13-hydroxy-18-acetoxy-17-methoxy-3,4epoxycembra-7,11-dien-16,14-olide.

The positive HR-ESI-MS of durumolide $\mathrm{P}$ (4) exhibited a pseudomolecular ion peak at $m / z 387.2148[\mathrm{M}+\mathrm{Na}]^{+}$, consistent with a molecular formula of $\mathrm{C}_{21} \mathrm{H}_{32} \mathrm{O}_{5}$, which is 16 mass units smaller than that of $\mathbf{1}$. Comparison of the NMR data (Tables 2 and 3) of both compounds showed that 4 exhibited the same framework of an $\alpha$-methoxymethyl- $\gamma$-lactone-containing cembranolide as $\mathbf{2}$, with the exception of signals assigned to $\mathrm{C}-13$, where the oxymethine in $\mathbf{2}$ was replaced by a methylene $\left[\delta_{\mathrm{H}} 2.54(1 \mathrm{H}, \mathrm{m})\right.$ and $\left.2.45(1 \mathrm{H}, \mathrm{m}) ; \delta_{\mathrm{C}} 43.7\left(\mathrm{CH}_{2}\right)\right]$ in 4 . The observed COSY correlation between $\mathrm{H}-13$ and $\mathrm{H}-14$ and the key $\mathrm{HMBC}$ correlations from $\mathrm{H}_{3}-20$ to $\mathrm{C}-13$ confirmed the location of the methylene group. The relative stereochemistry of $\mathbf{4}$ was in agreement with that of $\mathbf{2}$ due to the similar NOESY correlations. Judging from the undisputable evidence, the structure of $\mathbf{4}$ was unambiguously determined and deduced as $\left(1 R^{*}, 3 R^{*}, 4 S^{*}, 14 S^{*}, 15 S^{*}, 7 E, 11 E\right)$-18-hydroxy-17-methoxy-3,4-epoxycembra-7,11-dien16,14-olide.

Table 3. ${ }^{1} \mathrm{H}$ NMR data ${ }^{a}$ for compounds $\mathbf{4}$ and $\mathbf{5}$.

\begin{tabular}{cll}
\hline & \multicolumn{1}{c}{4} & \multicolumn{1}{c}{$\mathbf{5}$} \\
\hline 1 & $2.51 \mathrm{~m}$ & $2.41 \mathrm{~m}$ \\
2 & $1.95 \mathrm{ddd}(14.4,4.0,2.0)^{b}$ & $1.98 \mathrm{~d}(14.4)$ \\
& $1.45 \mathrm{ddd}(14.4,7.2,2.4)$ & $1.09 \mathrm{~m}$ \\
3 & $2.90 \mathrm{dd}(7.2,4.0)$ & $2.52 \mathrm{~m}$ \\
5 & $2.37 \mathrm{~m}$ & $2.08 \mathrm{~m}$ \\
& $1.21 \mathrm{ddd}(14.8,12.8,4.0)$ & $1.14 \mathrm{ddd}(11.6,10.4,2.4)$ \\
6 & $2.33 \mathrm{~m}$ & $2.29 \mathrm{~m}$ \\
& $2.15 \mathrm{~m}$ & $2.11 \mathrm{~m}$ \\
7 & $5.09 \mathrm{dd}(6.4,4.4)$ & $5.05 \mathrm{br} \mathrm{d}(9.6)$ \\
9 & $2.29 \mathrm{~m}$ & $2.35 \mathrm{~m}$ \\
& $2.13 \mathrm{~m}$ & $2.17 \mathrm{~m}$ \\
10 & $2.26 \mathrm{~m}$ & $2.54 \mathrm{~m}$ \\
& $2.13 \mathrm{~m}$ & $2.17 \mathrm{~m}$ \\
11 & $5.17 \mathrm{t}(7.6)$ & $5.50 \mathrm{dd}(7.6,2.8)$ \\
13 & $2.54 \mathrm{~m}$ & $4.08 \mathrm{~d}(8.8)$ \\
& $2.45 \mathrm{~m}$ & $4.03 \mathrm{dd}(8.8,8.4)$ \\
14 & $4.13 \mathrm{ddd}(10.0,8.4,3.2)$ & $2.49 \mathrm{t}(2.8)$ \\
15 & $2.48 \mathrm{~m}$ & $3.83 \mathrm{dd}(9.6,2.8)$ \\
17 & $3.81 \mathrm{dd}(9.6,3.2)$ & $3.79 \mathrm{dd}(9.6,2.8)$ \\
& $3.77 \mathrm{dd}(9.6,3.2)$ & $1.21 \mathrm{~s}$ \\
18 & $3.85 \mathrm{dd}(12.0,5.2)$ & $1.63 \mathrm{~s}$ \\
& $3.55 \mathrm{dd}(12.05 .2)$ & $1.72 \mathrm{~s}$ \\
19 & $1.60 \mathrm{~s}$ & $3.39 \mathrm{~s}$ \\
\hline
\end{tabular}

${ }^{a}$ Spectra were measured in $\mathrm{CDCl}_{3}(400 \mathrm{MHz}){ }^{b} J$ values (in $\mathrm{Hz}$ ) are in parentheses. 
The molecular formula of $\mathrm{C}_{21} \mathrm{H}_{32} \mathrm{O}_{5}$ was assigned to 5 from its HR-ESI-MS and ${ }^{13} \mathrm{C}$ NMR data (Table 2), indicating six degrees of unsaturation. The NMR data (Tables 2 and 3) of 5 were highly compatible with those obtained for durumolide $\mathrm{J}$ [11], with the replacement of the $\alpha$-methylene- $\gamma$-lactone with an $\alpha$-methoxymethyl- $\gamma$-lactone being the most noticeable difference. The methoxymethyl moiety attached to $\mathrm{C}-15$ was inferred from the ${ }^{1} \mathrm{H}-{ }^{1} \mathrm{H}$ COSY and HMBC correlations. Moreover, the $15 S$ configuration was confirmed by the key NOESY correlation between $\mathrm{H}-17 / \mathrm{H}-1$ and $\mathrm{H}-1 / \mathrm{H}-3$. The appropriate stereochemistry of $\mathbf{5}$ was determined by spectroscopic method according to Mosher's acylation for absolute configuration determination of chiral alcohols [10]. Analysis of the $\Delta \delta_{S-R}$ values (Figure 6) according to the Mosher model pointed to an $R$ configuration for C-13 of $\mathbf{5}$, because $\mathrm{H}_{2}-10, \mathrm{H}-11$, Me-19, and Me-20 of $(S)$-MTPA ester 5a were less shielded by the phenyl ring of MTPA products. Therefore, the absolute stereochemistry of 5 was unambiguously established as $(1 R, 3 R, 4 R, 13 R, 14 R, 15 S, 7 E, 11 E)$-13-hydroxy-17-methoxy-3,4-epoxycembra-7,11-dien-16,14-olide.

Figure 6. ${ }^{1} \mathrm{H}-\mathrm{NMR}$ chemical shift differences $\left(\Delta \delta=\delta_{S}-\delta_{R}\right)$ of the MTPA esters in pyridine- $d_{5}$.

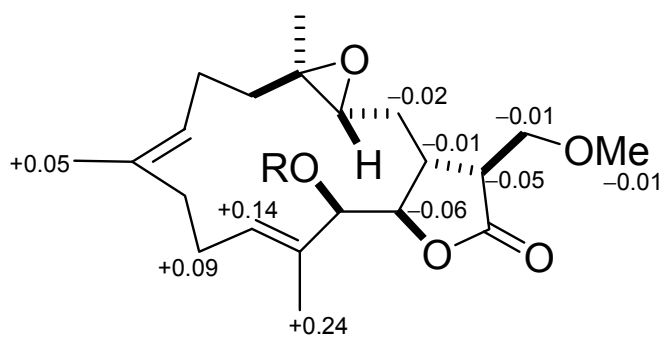

5a $\quad \mathrm{R}=\mathrm{S}-\mathrm{MTPA}$

5b $\quad \mathrm{R}=R-\mathrm{MTPA}$

The determination of the configurations of $\gamma$-lactone ring fused to 14 -membered ring at $\mathrm{C}-1$ and C-14 based on the coupling constant between the lactonic methine protons $\left({ }^{3} J_{1,14}\right)$ is dubious [8]. Notably, all of the cis-fused lactones at C-1 and C-14 of cembranolides from the Caribbean gorgonians Eunicea succinea and Eunicea mammosa for which an X-ray analysis has been performed [23] and all trans-fused lactones of durumolides $\mathrm{M}-\mathrm{Q}$ (1-5) were confirmed after determination of the ring junction of durumolides $\mathrm{A}-\mathrm{L}$ and durumhemiketalolides $\mathrm{A}-\mathrm{C}$ using X-ray data and biogenetic considerations [10-12].

The possibility that 1 and $\mathbf{2}$ were furnished via Micheal addition [24,25] of sinularolide B [22] in $\mathrm{MeOH}$ resulting in addition of a methoxy group to $\alpha$-methylene- $\gamma$-lactone should not be excluded. In order to ascertain $\mathbf{1}$ and $\mathbf{2}$, having an $\alpha$-methoxymethyl- $\gamma$-lactone ring, to be natural or artificial products from sinularolide B through the isolation process, the following experiments were conducted. A solution of sinularolide B was kept at room temperature for 3 days in the presence of Si-60 or RP-18 gel in $\mathrm{MeOH}$. The formation of $\mathbf{1}$ and $\mathbf{2}$ were not observed. Apparently, compounds $\mathbf{1}$ and $\mathbf{2}$ are natural products. Similarly, compounds 3-5, possessing the same functionality, may also be natural products.

Compounds $\mathbf{1}-\mathbf{5}$ in the present study were evaluated in vitro for cytotoxicity against P-388, A-459 and HT-29 cancer cell lines using the MTT assay, and antiviral activity against human cytomegalovirus. Preliminary cytotoxic screening revealed that compound $\mathbf{4}$ exhibited cytotoxicity against P-388 (mouse 
lymphocytic leukemia) cell line with an $\mathrm{ED}_{50}$ of $3.8 \mu \mathrm{g} / \mathrm{mL}$. Moreover, compound 5 showed significant antiviral activity against human cytomegalovirus with an $\mathrm{IC}_{50}$ of $5.2 \mu \mathrm{g} / \mathrm{mL}$.

\section{Experimental Section}

\subsection{General Experimental Procedures}

Optical rotations were determined with a JASCO P1020 digital polarimeter. Ultraviolet (UV) and infrared (IR) spectra were obtained on a JASCO V-650 and JASCO FT/IR-4100 spectrophotometers, respectively. The NMR spectra were recorded on a Varian MR $400 \mathrm{NMR}$ spectrometer at $400 \mathrm{MHz}$ for ${ }^{1} \mathrm{H}$ and $100 \mathrm{MHz}$ for ${ }^{13} \mathrm{C}$ or on a Varian Unity INOVA $500 \mathrm{FT}-\mathrm{NMR}$ spectrometer at $500 \mathrm{MHz}$ for ${ }^{1} \mathrm{H}$ and $125 \mathrm{MHz}$ for ${ }^{13} \mathrm{C}$, respectively. Chemical shifts are expressed in $\delta$ (ppm) referring to the solvent peaks $\delta_{\mathrm{H}} 7.27$ and $\delta_{\mathrm{C}} 77.0$ for $\mathrm{CDCl}_{3}$, respectively, and coupling constants are expressed in $\mathrm{Hz}$. ESI-MS were recorded by ESI FT-MS on a Bruker APEX II mass spectrometer. Silica gel 60 (Merck, Germany, 230-400 mesh) and LiChroprep RP-18 (Merck, 40-63 $\mu \mathrm{m}$ ) were used for column chromatography. Precoated silica gel plates (Merck, Kieselgel $60 \mathrm{~F}_{254}, 0.25 \mathrm{~mm}$ ) and precoated RP-18 $\mathrm{F}_{254 \mathrm{~s}}$ plates (Merck) were used for thin-layer chromatography (TLC) analysis. High-performance liquid chromatography (HPLC) was carried out using a Hitachi L-7100 pump equipped with a Hitachi L-7400 UV detector at $220 \mathrm{~nm}$ together with a semi-preparative reversed-phase column (Merck, Hibar LiChrospher RP-18e, $5 \mu \mathrm{m}, 250 \times 25 \mathrm{~mm}$ ).

\subsection{Animal Material}

The soft coral $L$. durum was collected by hand using SCUBA along the coast reefs offshore from the Dongsha Atoll in June 2007, at a depth of $8 \mathrm{~m}$, and was stored in a freezer for two months until extraction. Identification was kindly verified by Prof. Chang-Feng Dai, Institute of Oceanography, National Taiwan University, Taiwan. A voucher specimen (TS-13) was deposited in the Department of Marine Biotechnology and Resources, National Sun Yat-sen University, Taiwan.

\subsection{Extraction and Isolation}

The frozen soft coral ( $1 \mathrm{~kg})$ was chopped into small pieces and extracted exhaustively by maceration with fresh acetone for $24 \mathrm{~h}$ at room temperature. The quantity of solvent used for each extraction $(2 \mathrm{~L})$ was at least three times the amount of the soft coral material used. The acetone extracts were filtered and concentrated under vacuum to yield a brownish oily residue, which was subsequently partitioned between EtOAc and $\mathrm{H}_{2} \mathrm{O}$. The resulting EtOAc-soluble residue (30 g) was subjected to column chromatography on silica gel using $n$-hexane with increasing amounts of EtOAc, and finally $100 \% \mathrm{MeOH}$ as elution, to obtain roughly 30 fractions on the basis of ${ }^{1} \mathrm{H}$ NMR data and TLC analyses. Fraction $18(2.16 \mathrm{~g})$ eluted with $n$-hexane-EtOAc $(1: 8)$ was subjected to a silica gel column using $n$-hexane-EtOAc mixtures of increasing polarity for elution, to furnish 14 subfractions. A subfraction 18-8 (507 mg) eluted with $n$-hexane-EtOAc (1:2) was fractionated to column chromatography on an ODS column using aq $\mathrm{MeOH}$ to afford six subfractions. Subsequently, a subfraction 18-8-1 (47 mg) eluted with $\mathrm{MeOH}-\mathrm{H}_{2} \mathrm{O}$ (45:55) was further purified by HPLC (RP-18) using 70\% aq $\mathrm{MeOH}$ to give $\mathbf{1}(2 \mathrm{mg})$ and $\mathbf{2}(1 \mathrm{mg})$. Similarly, $3(1 \mathrm{mg})$, and 5 (3 mg) were obtained 
by separation of a subfraction 18-8-2 (267 mg) eluted with $\mathrm{MeOH}-\mathrm{H}_{2} \mathrm{O}$ (55:45) on HPLC (RP-18) using 70\% MeOH in $\mathrm{H}_{2} \mathrm{O}$. Similarly, a subfraction 18-8-4 (46 mg) eluted with $\mathrm{MeOH}-\mathrm{H}_{2} \mathrm{O}(65: 35)$ was further applied to HPLC (RP-18) using 70\% $\mathrm{MeOH}$ in $\mathrm{H}_{2} \mathrm{O}$ to provide 4 (2 mg).

Durumolide M (1): colorless oil; $[\alpha]^{25}{ }_{\mathrm{D}}-45$ (c 0.1, $\left.\mathrm{CHCl}_{3}\right)$; IR (KBr) v $\max 3394,2924,1766,1449$, 1027, $765 \mathrm{~cm}^{-1}$; ${ }^{1} \mathrm{H}-\mathrm{NMR}\left(\mathrm{CDCl}_{3}, 400 \mathrm{MHz}\right)$ and ${ }^{13} \mathrm{C}-\mathrm{NMR}\left(\mathrm{CDCl}_{3}, 100 \mathrm{MHz}\right)$ data, see Tables 1 and 2; ESI-MS $m / z 403$ [M + Na] ${ }^{+}$HR-ESI-MS $m / z 403.2099$ (calcd for $\mathrm{C}_{21} \mathrm{H}_{32} \mathrm{O}_{6} \mathrm{Na}, 403.2096$ ).

Durumolide N (2): colorless oil; $[\alpha]^{25}-98$ (c 0.1, $\left.\mathrm{CHCl}_{3}\right)$; IR (KBr) $v_{\max } 3436,2926,1766,1386$, $1178,1033 \mathrm{~cm}^{-1} ;{ }^{1} \mathrm{H}-\mathrm{NMR}\left(\mathrm{CDCl}_{3}, 500 \mathrm{MHz}\right)$ and ${ }^{13} \mathrm{C}-\mathrm{NMR}\left(\mathrm{CDCl}_{3}, 125 \mathrm{MHz}\right)$ data, see Tables 1 and 2; ESI-MS m/z 403 [M + Na] ${ }^{+}$; HR-ESI-MS m/z 403.2094 (calcd for $\mathrm{C}_{21} \mathrm{H}_{32} \mathrm{O}_{6} \mathrm{Na}, 403.2096$ ).

Durumolide O (3): colorless oil; $[\alpha]^{25}-94$ (c 0.1, $\left.\mathrm{CHCl}_{3}\right)$; IR (KBr) $v_{\max } 3425,2924,1773,1460$, $1181,1035 \mathrm{~cm}^{-1} ;{ }^{1} \mathrm{H}-\mathrm{NMR}\left(\mathrm{CDCl}_{3}, 500 \mathrm{MHz}\right)$ and ${ }^{13} \mathrm{C}-\mathrm{NMR}\left(\mathrm{CDCl}_{3}, 125 \mathrm{MHz}\right)$ data, see Tables 1 and 2; ESI-MS $m / z 445[\mathrm{M}+\mathrm{Na}]^{+}$; HR-ESI-MS $m / z 445.2199$ (calcd for $\mathrm{C}_{23} \mathrm{H}_{34} \mathrm{O}_{7} \mathrm{Na}, 445.2202$ ).

Durumolide P (4): colorless oil; $[\alpha]^{25}-121$ (c 0.1, $\left.\mathrm{CHCl}_{3}\right)$; IR (KBr) $v_{\max } 3460,2926,1769,1445$, $1181,1031 \mathrm{~cm}^{-1} ;{ }^{1} \mathrm{H}-\mathrm{NMR}\left(\mathrm{CDCl}_{3}, 400 \mathrm{MHz}\right)$ and ${ }^{13} \mathrm{C}-\mathrm{NMR}\left(\mathrm{CDCl}_{3}, 100 \mathrm{MHz}\right)$ data, see Tables 1 and 2; ESI-MS $m / z 387$ [M + Na] ${ }^{+}$; HR-ESI-MS $m / z 387.2148$ (calcd for $\mathrm{C}_{21} \mathrm{H}_{32} \mathrm{O}_{5} \mathrm{Na}, 387.2147$ ).

Durumolide Q (5): colorless oil; [ $\alpha]^{25}{ }_{\mathrm{D}}-99\left(c\right.$ 0.2, $\left.\mathrm{CHCl}_{3}\right)$; IR (KBr) $v_{\max } 3446,2924,1773,1383$, 1177, $1031 \mathrm{~cm}^{-1}$; ${ }^{1} \mathrm{H}-\mathrm{NMR}\left(\mathrm{CDCl}_{3}, 400 \mathrm{MHz}\right)$ and ${ }^{13} \mathrm{C}-\mathrm{NMR}\left(\mathrm{CDCl}_{3}, 100 \mathrm{MHz}\right)$ data, see Tables 2 and 3; ESI-MS $m / z 387$ [M + Na] ${ }^{+}$; HR-ESI-MS $m / z 387.2146$ (calcd for $\mathrm{C}_{21} \mathrm{H}_{32} \mathrm{O}_{5} \mathrm{Na}, 387.2147$ ).

Preparation of Mosher's Esters of 5: In separate NMR tubes, duplicate (1.0 mg) samples of 5 were dissolved in $0.6 \mathrm{~mL}$ of pyridine- $d_{5}$ and allowed to react for $3 \mathrm{hr}$ at room temperature with $(R)$ - and $(S)$-MTPA chloride (one drop) to yield (S)-MTPA ester 5a and $(R)$-MTPA ester 5b, respectively. Selected ${ }^{1} \mathrm{H}-\mathrm{NMR}$ (pyridine- $\left.d_{5}, 300 \mathrm{MHz}\right)$ of 5a: $\delta_{\mathrm{H}} 7.41-7.61(5 \mathrm{H}, \mathrm{m}, \mathrm{Ph}), 5.93(1 \mathrm{H}, \mathrm{br} \mathrm{d}, J=8.9 \mathrm{~Hz}$, H-13), 5.74 (1H, m, H-11), $5.00(1 \mathrm{H}$, br d, $J=9.1 \mathrm{~Hz}, \mathrm{H}-7), 4.44$ (1H, t, $J=8.9 \mathrm{~Hz}, \mathrm{H}-14), 4.01$ (2H, m, H $2-17), 3.26$ (3H, s, OMe), 2.88 (1H, m, H-15), 2.82 (1H, br s, H-1), 2.47 (2H, m, H $\left.\mathrm{H}_{2}-10\right), 2.20$ $\left(2 \mathrm{H}, \mathrm{m}, \mathrm{H}_{2}-6\right), 1.95$ (2H, m, H $\left.2-2\right), 1.78$ (3H, s, Me-20), 1.54 (3H, s, Me-19), 1.21 (3H, s, Me-18); Selected ${ }^{1} \mathrm{H}-\mathrm{NMR}$ (pyridine- $d_{5}, 300 \mathrm{MHz}$ ) of $\mathbf{5 b}: 7.42-7.63(5 \mathrm{H}, \mathrm{m}, \mathrm{Ph}), 5.83(1 \mathrm{H}, \mathrm{br} \mathrm{d}, J=8.4 \mathrm{~Hz}$, H-13), 5.60 (1H, m, H-11), 4.94 (1H, br d, $J=8.9 \mathrm{~Hz}, \mathrm{H}-7), 4.50$ (1H, t, $J=8.9 \mathrm{~Hz}, \mathrm{H}-14), 4.02$ (2H, m, H $\left.{ }_{2}-17\right), 3.27$ (3H, s, OMe), 2.93 (1H, m, H-15), 2.83 (1H, m, H-1), 2.38 (2H, m, H $\left.2-10\right), 2.19$ (2H, m, H2-6), 1.97 (2H, m, H $2-2), 1.54$ (3H, s, Me-20), 1.49 (3H, s, Me-19), 1.16 (3H, s, Me-18).

\subsection{Cytotoxicity Assay}

Cytotoxicity was determined against P-388 (mouse lymphocytic leukemia), HT-29 (human colon adenocarcinoma), and A-549 (human lung epithelial carcinoma) tumor cells using a modification of the MTT colorimetric method. The provision of the P-388 cell line was supported by J. M. Pezzuto, formerly of the Department of Medicinal Chemistry and Pharmacognosy, University of Illinois at Chicago. HT-29 and A-549 cell lines were purchased from the American Type Culture Collection. The experimental details of this assay were carried out according to a previously described procedure [11,26,27]. 


\subsection{Anti-HCMV Assay}

To determine the effects of natural products upon the HCMV cytopathic effect (CPE), confluent human embryonic lung (HEL) cells grown in 24-well plates will be incubated for $1 \mathrm{~h}$ in the presence or absence of various concentrations of tested natural product. Then, cells will be infected with HCMV at an input of 1000 plaque forming units (pfu) per well of a 24-well dish. Antiviral activity is expressed as $\mathrm{IC}_{50}(50 \%$ inhibitory concentration), or the compound concentration required to reduce the virus induced CPE by $50 \%$ after 7 days as compared with the untreated control. To monitor the cell growth upon treating with natural products, an MTT-colorimetric assay was employed [28].

\section{Conclusions}

Comparison of cytotoxicity of durumolides $\mathrm{M}-\mathrm{Q}(\mathbf{1}-\mathbf{5})$ with those of cembranolides previously isolated by our group from Lobophtum michaelae [29], showed that methoxylation at C-17 reduced cytotoxicity against the same cancer cell lines.

\section{Acknowledgments}

This research was financially supported by grants from the National Science Council (NSC99-2628-B-110-002-MY3) and Ministry of Education of Taiwan awarded to C.-Y.D.

\section{References}

1. Blunt, J.W.; Copp, B.R.; Hu, W.P.; Munro, M.H.G.; Northcote, P.T.; Prinsep, M.R. Marine natural products. Nat. Prod. Rep. 2009, 26, 170-244.

2. Wang, S.-K.; Duh, C.-Y.; Wu, Y.-C.; Wang, Y.; Cheng, M.-C.; Soong, K.; Fang, L.-S. Cytotoxic cembranolides from the soft coral Lobophytum michaelae. J. Nat. Prod. 1992, 55, 1430-1435.

3. Coval, S.J.; Patton, R.W.; Petrin, J.M.; James, L.; Rothofsky, M.L.; Lin, S.L.; Patel, M.; Reed, J.K.; McPhil, A.T.; Bishop, W.R. A cembranolide diterpene farnesyl protein transferase inhibitor from the marine soft coral Lobophytum cristagalli. Bioorg. Med. Chem. Lett. 1996, 6, 909-912.

4. Higuchi, R.; Miyamoto, T.; Yamada, K.; Komori, T. Cytotoxic and ichthyotoxic compounds from marine opisthobranchia and soft coral. Toxicon 1998, 36, 1703-1705.

5. Matthee, G.F.; König, G.M.; Wright, A.D. Three new diterpenes from the marine soft coral Lobophytum crassum. J. Nat. Prod. 1998, 61, 237-240.

6. Duh, C.-Y.; Wang, S.-K.; Huang, B.-T.; Dai, C.-F. Cytotoxic cembrenolide diterpenes from the Formosan soft coral Lobophytum crassum. J. Nat. Prod. 2000, 63, 884-885.

7. Chao, C.-H.; Hang, H.-C.; Wu, Y.-C.; Lu, C.-K.; Dai, C.-F.; Sheu, J.-H. Glycolipids from the Formosan soft coral Lobophytum crassum. Chem. Pharm. Bull. 2007, 55, 1720-1723.

8. Zhang, W.; Krohn, K.; Ding, J.; Miao, Z.-H.; Zhou, X.-H.; Chen, S.-H.; Pescitelli, G.; Salvadori, P.; Kurtan, T.; Guo, Y.-W. Structural and stereochemical studies of $\alpha$-methylene- $\gamma$-lactone-bearing cembrane diterpenoids from a south China sea soft coral Lobophytum crassum. J. Nat. Prod. 2008, 71, 961-966.

9. Lin, S.-T.; Wang, S.-K.; Cheng, S.-Y.; Duh, C.-Y. Lobocrasol, a new diterpenoid from the soft coral Lobophytum crassum. Org. Lett. 2009, 14, 3012-3014. 
10. Cheng, S.-Y.; Wen, Z.-H.; Chiou, S.-F.; Wang, S.-K.; Hsu, C.-H.; Dai, C.-F.; Chiang, M.Y.; Duh, C.-Y. Durumolides A-E, Anti-inflammatory and antibacterial cembranolides from the soft coral Lobophytum durum. Tetrahedron 2008, 64, 9698-9704.

11. Cheng, S.-Y.; Wen, Z.-H.; Wang, S.-K.; Chiou, S.-F.; Hsu, C.-H.; Dai, C.-F.; Duh, C.-Y. Anti-inflammatory cembranolides from the soft coral Lobophytum durum. Bioorg. Med. Chem. 2009, 17, 3763-3769.

12. Cheng, S.-Y.; Wen, Z.-H.; Chiou, S.-F.; Wang, S.-K.; Hsu, C.-H.; Dai, C.-F.; Chiang, M.Y.; Duh, C.-Y. Unprecedented hemiketal cembranolides with anti-inflammatory activity from the soft coral Lobophytum durum. J. Nat. Prod. 2009, 72, 152-155.

13. Rashid, M.A.; Gustafson, K.R.; Boyd, M.R. HIV-inhibitory cembrane derivatives from a Philippines collection of the soft coral Lobophytum species. J. Nat. Prod. 2000, 63, 531-533.

14. Kashman, Y.; Groweiss, A. Lobolide: A new epoxy cembranolide from marine origin. Tetrahedron Lett. 1977, 13, 1159-1160.

15. Kashman, Y.; Carmely, S.; Groweiss, A. Further cembranoid derivatives from the Red Sea soft corals Alcyonium flaccidum and Lobophytum crassum. J. Org. Chem. 1981, 46, 3592-3596.

16. Kinamoni, Z.; Groweiss, A.; Carmely, S.; Kashman, Y. Several new cembranoid diterpenes from three soft corals of the Red Sea. Tetrahedron 1983, 39, 1643-1648.

17. Bowden, B.F.; Coll, J.C.; Tapiolas, D.M. Studies of Australian soft corals. XXXШ. New cembranoid diterpenes from a Lobophytum species. Aust. J. Chem. 1983, 36, 2289-2295.

18. Bowden, B.F.; Coll, J.C.; Decosta, M.S.L.; Desilva, E.D.; Mackay, M.F.; Mahendran, M.; Willis, R.H. The structure determination of a new cembranolide diterpene from the soft coral Lobophytum cristigalli (Coelenterata, Octocorallia, Alcyonacea). Aust. J. Chem. 1984, 34, 545-552.

19. Bowden, B.F.; Coll, J.C.; Heaton, A.; Konig, G.; Bruck, M.A.; Cramer, R.E.; Klein, D.M.; Scheuer, P.J. The structures of four isomeric dihydrofuran-containing cembranoid diterpenes from several species of soft coral. J. Nat. Prod. 1987, 50, 650-659.

20. Subrahmanyam, C.; Rao, C.V.; Anjaneyulu, V.; Satyanarayana, P.; Rao, P.V.S. New diterpenes from a new species of Lobophytum soft coral of the South Andaman coast. Tetrahedron 1992, 48, 3111-3120.

21. Yamada, K.; Ryu, K.; Miyamoto, T.; Higuchi, R. Bioactive terpenoids from octocorallia. 4. Three new cembrane-type diterpenoids from the soft coral Lobophytum schoedei. J. Nat. Prod. 1997, 60, 798-801.

22. Li, G.; Zhang, Y.; Deng, Z.; van Ofwegen, L.; Proksch, P.; Lin, W. Cytotoxic cembranoid diterpenes from a soft coral Sinularia gibberosa. J. Nat. Prod. 2005, 68, 649-652.

23. Morales, J.J.; Espina, J.R.; Rodríguez, A.D. The structure of euniolide, a new cembranoid from the Caribbean gorgonians Eunicea succinea and Eunicea mammosa. Tetrahedron 1990, 46, 5889-5894.

24. Uchio, Y.; Eguchi, S.; Kuramoto, J.; Nakayama, M.; Hase, T. Lobochedleolide and (7Z)-lobochedleolide, new cembranolides from the soft coral Lobophytum hedleyl Whitelegge. Tetrahedron Lett. 1981, 22, 4089-4092. 
25. Rodríguez, A.D.; Piña, I.C.; Acosta, A.L.; Ramírez, C.; Soto, J.J. Synthesis of analogues of Eunicea $\gamma$-cembranolides containing cyclic ethers via saponification. J. Org. Chem. 2001, 66, 648-658.

26. Geran, R.I.; Greenberg, N.H.; MacDonald, M.M.; Schumacher, A.M.; Abbott, B.J. Protocols for screening chemical agents and natural products against animal tumors and other biological syatems. Cancer Chemother. Rep. 1972, 3, 51-61.

27. Hou, R.-S.; Duh, C.-Y.; Chiang, M.Y.; Lin, C.-N. Sinugibberol, a new cytotoxic cembranoid diterpene from the soft coral Sinularia gibberosa. J. Nat. Prod. 1995, 58, 1126-1130.

28. Stevens, M.; Balzarini, J.; Tabarrini, O.; Andrei, G.; Snoeck, R.; Cecchetti, V.; Fravolini, A.; De Clercq, E.; Pannecouque, C. Cell-dependent interference of a series of new 6-aminoquinolone derivatives with viral (HIV/CMV) transactivation. J. Antimicrob. Chemother. 2005, 56, 847-855.

29. Wang, L.-T.; Wang, S.-K.; Soong, K.; Duh, C.-Y. New cytotoxic cembranolides from soft coral Lobophytum michaelae. Chem. Pharm. Bull. 2007, 55, 766-770.

Samples Availability: Not Available.

(C) 2011 by the authors; licensee MDPI, Basel, Switzerland. This article is an open access article distributed under the terms and conditions of the Creative Commons Attribution license (http://creativecommons.org/licenses/by/3.0/). 